
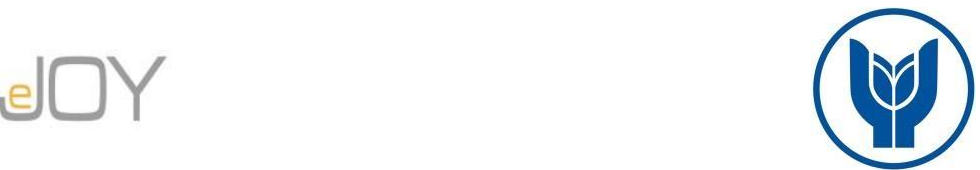

Karahan, M., Patır, S., Gedik, Y. / Journal of Yasar University, 2021, 16/63, 1496-1513

\title{
Üniversite Öğrencilerinin Kendine Güven ve Risk Alma Davranışları ile Yenilikçilik Düzeyleri Arasındaki İlişsilerin İncelenmesi
}

\section{Examining the Relationships Between University Students' Self-Confidence and Risk-Taking Behaviours and Their Innovativeness Levels}

\author{
Mehmet KARAHAN, Firat University, Turkey, m.karahan@ firat.edu.tr \\ Orcid No: 0000-0002-0402-0020 \\ Sait PATIR, Bingol University, Turkey, spatir@bingol.edu.tr \\ Orcid No: 0000-0002-1592-1094 \\ Yeliz GEDİK, Firat University, Turkey, ygedik@firat.edu.tr \\ Orcid No: 0000-0003-2795-9302
}

\begin{abstract}
Öz: Teknolojik gelişmelerin hızla yayıldı̆̆ günümüzde yenilikçi bir anlayışı benimseyen ve risk alabilen bireylerin, oluşan yeni yapılanmaya uyum sağlama ve başarıy yakalamada daha fazla şansları olacaktır. Yaşanan bu hızlı değişimle birlikte insanların bireysel anlamdaki gelişiminin de bu denli hızlı olması uyum anlamında bir gereklilik olmuştur. Bu düşünceden hareketle yenilik kapasitesine önemli etkileri olduğu düşünülen bireysel yenilikçilik ile risk alma davranışı arasındaki ilişkinin analizi oldukça önemlidir. Bu bağlamda çalışmada, üniversite ögrencilerinin yenilikçilik ile kendine güven ve risk alma davranışları arasındaki ilişkilerin incelenmesine karar verilmiştir. Çalışma için gerekli olan verileri elde etmek için Firat Üniversitesi’nde ögrenim gören ve rastgele seçilen 504 ögrenciye yüz yüze görüşme yöntemiyle bir anket çalışmasl yapılmıştır. Elde edilen verilerle gerekli istatistiksel analizler yapılarak bulgular yorumlanmış, üniversite ögrencilerinin yenilikçilik ile kendine güven ve risk alma davranışları arasındaki ilişki sorgulanmış, ögrenciler arasında yenilikçilik ve kendine güven ve risk alma seviyelerinin artırılabilmesi için yapılması gerekenler belirlenmeye çalışılmıştır. Çalışmadan elde edilen sonuçlara göre, yenilikçilik düzeyi ile kendine güven ve risk alma düzeyleri arasında pozitif yönde ve anlamlı bir ilişki olduğu belirlenmiş ve bu sonuca göre öğrencilerin kendine güven ve risk alma düzeyleri arttıkça, yenilikçilik düzleri de artmaktadır yorumu yapılmıştır.
\end{abstract}

Anahtar Kelimeler: Yenilikçilik, Bireysel Yenilik, Kendine Güven, Risk Alma Davranışl, Korelasyon

JEL Siniflandırmasl: O31, O32, D81, C16

Abstract: In a world where technological developments are spreading rapidly, people who adopt an innovative understanding and can take risks will have more chances to adapt to the new structure and achieve success. Experiencing rapid changes along with technological developments made it necessary for individuals to adapt to new situations. With this in mind, it is very important to analyse the relationship between individual innovativeness and risk-taking behaviour, which is thought to have significant effects on innovation capacity. In this context, it was decided to examine the relationship between innovativeness, self-confidence and risk-taking behaviours of university students. In order to obtain the data required for the study, a questionnaire study was conducted using face-to-face interview method with randomly selected 504 students studying at Firat University. The findings were interpreted by performing necessary statistical analyses with the obtained data, and the relationship between innovativeness and self-confidence and risk-taking behaviours of university students was questioned. It was tried to determine what needs to be done in order to increase the level of innovation and self-confidence and risk taking among the students. According to the results obtained from the study, it was determined that there is a positive and significant relationship between innovativeness level and self-confidence and risk-taking levels and according to this result, it is commented that as students' self-confidence and risk-taking levels increase, their level of innovation also increases.

Keywords: Innovation, Individual Innovation, Self-Confidence, Risk Taking Behaviour, Correlation

JEL Classification: O31, O32, D81, C16

Makale Gecmiși / Article History

Başvuru Tarihi / Date of Application Kabul Tarihi / Acceptance Date
: 6 Mart / March 2021

: 25 Haziran / June 2021 


\section{Giriş}

Yenilikçilik yeteneği, pazar ihtiyaçlarını karşılayacak yeni ürünlerin, daha yeni teknolojilerin geliştirilmesine imkan sağlayan teknolojik süreçler ve öngörülemeyen teknolojik değişikliklere, faliyetlere cevap verebilecek yenilikler geliştirme yeteneği olarak tanımlanabilir (Uzkurt, 2008). Yenilik kapasitesi, bireysel olarak ölçülebilir. Bireysel olarak yenilikleri arayıp bulma arzusu olarak ifade edilen bu terim, insanların hayatı boyunca karşılaştı̆̆ yeni şeyleri ve fikirleri çabukça kabul etme, benimseme düzeyidir (Kara, 2019: 52). Bireysel yenilikçilik; risk alma, deneyimlere açık olma ve fikirleri sürekli geliştirme, fikir liderliği gibi kavramları da içerisine alan bir kavramdır.

Yenilik, birey ve ait olduğu topluluk tarafından yeni olarak tanımlanan her türlü düşünce, nesne ve uygulamadır (Demiralay vd., 2016). Bireysel yenilikçilik ise, yeni olana aitlik hissederek onu geliştirmek ya da uygulamaktır. Bireysel yenilikçilik, bireylerin yeni olan durum, olay, mal veya hizmete adapte olabilme, risk alma, benimseme, hoşgörü gösterme ve yeniye özgü tecrübelere açık olmaktır (Korucu ve Olpak, 2015). Bireysel yenilikçilik bir disiplin, öğrenme ve öğrendiğini uygulayabilme becerisi olarak da değerlendirilebilmektedir (Drucker, 1985).

Bireysel yenilikçilik, insanların yaşamlarını daha güzel bir şekilde geçirmeleri veya sosyal yapılarını yenilemelerine katkı sağlar. Bununla birlikte bireysel ihtiyaçların gidermesi, yaşam koşullarının sürekli bir şekilde geliştirilmesini ve kişisel niteliklerin zenginleştirilmesini sağlamaktadır. Bilimsel ve teknolojik ilerlemeler bireyleri toplumdan önce değişime ve yeniliğe zorlar. Bireysel yenilik anlayışı, sosyal, kültürel ve uluslararası özellikleri bulunan yaşamsal değişimler arası, sağlıklı bir denge kurulabilmesi için çok önemlidir. Bireysel yenilikçilik alan yazınındaki ortak kanıya göre, bireyler ancak algılayabildikleri yenilikleri benimseyebilmekte ve bu yüzden bireysel düzeyde bir yenilik ön yargısı oluşturmak konuyla ilgili en önemli adımlardan birisidir (Karahan ve Patır, 2019).

Bireylerin yenilikçilik anlayışları, yaşanan toplumun kültürel değerleriyle evrensel özelliklere sahip yaşam yerlerindeki değişikliklerde, sağlıklı bir denge sağlanmasının gerektirir. $\mathrm{Bu}$ bağlamda yenilik; toplum, kültür ve idari manada yeni metot ve yaklaşımı kullanmak anlamında ifade edilse de aslında bu kavram, toplum içerisinde yaşayan bireylerin yaşamlarındaki tüm davranışlarla alakalı olduğunu söyleyebiliriz. Yenilik kavramı, bilgiyle ilişkilendirilebilen, bilginin fikirlere, davranış, ürün, hizmet ve sistemlere dönüştürülmesi süreçleri olarak da tanımlanabilir (Ünal, 2014).

Bireysel yenilik yeteneği yüksek olan bireyler, yenilik deneyimlerine açık olmakla birlikte yenilikleri yararlı ve önemli olarak algılayarak yola çıkmalıdırlar. Bu yeteneğe sahip kişiler, 
farklı tipteki yaşantılara göre kendilerini geliştirme yollarını ararken veya tesadüfen karşılaştıkları yeni bilgileri kişisel olarak öncekilerine alarak kullanma eğiliminde olurlar ve bunu gerçekleştirirken başkalarının düşüncelerini de değerlendirerek bunlardan öğrendikleriyle yeni bilgiler türetebilirler. Ayrıca bu kişiler, teknolojiyi benimseme ve uygulama hevesi yüksek olan bireylerdir. Yapılan çalışmalar incelendiğinde bu bireylerin "sorgulayıcı" karaktere sahip oldukları ileri sürülmektedir (Demiralay, 2016).

Bireysel yenilikçilik kavramı temelde yenilik ve yenilikçilik kavramlarını da kapsar ve yaşam boyu öğrenmeyi gerektirir. Birey veya kurumların değişime ve yenilikçiliğe karşı olan tepkilerini de içerir. Yenilikçilik, yeni olana bir şeye duyulan istek ve benimseme davranışıyla yeniliğe olumlu bir yaklaşım olarak da tanımlanabilir (Yılmaz ve Beşkaya, 2018: 159).

\section{Kendine Güven ve Risk Alma Davranışları}

Kendine güven; kişinin kendi çaba, yetenek ve becerilerine güvenerek hareket etmesi, başarılı olduğu zaman da bireysel güveni artırması ve dolayısı ile ne istediğini bilen, hedefine doğru harekete geçebilen ve hata bunu korkusuzca gerçekleştirmesi (Türkoğlu vd., 2017: 12), kendisi hakkında olumlu ve gerçekçi tutuma sahip olması, belirlediği hedefleri başarabileceğine inanmasıdır (Akkaya vd., 2014: 113).

Kendine güven, yeni bir işe başlandığında, bu işin üstesinden gelebilme gücü sağlar, böylelikle birey ihtiyacı olan motivasyonu elde etmiş olur. Özgüveni yüksek olan bireyler, kısıtlı kaynak ve zamanda yeni işler üstlenerek, zorlu işlerin üstesinden gelebilir. Bireylerin yapacakları işe dikkatlerini toplamasını sağlayan özgüven, kişinin performansını da önemli derecede etkilemektedir (Bozkurt ve Erdurur, 2013: 60).

Genellikle kendi işini kuran veya kurmaya niyetlenen kişilerin kendine güvenen birisi olduğu kabul edilir ve bu nedenle kişinin belirlediği amaçları gerçekleştirebileceğine inanması olarak ta tanımlanabilmektedir. Kendine güven ifadesi literatürde; kendi kendini kontrol eden, risk alabilen, karmaşık ve belirsizlik ortamları ve psikolojik baskılar gibi davranışlardan birisi olduğu ileri sürülmektedir (Özden, Temurlenk ve Başar, 2008).

Günümüzde yaşanan hızlı değişimlerin sonucunda artan belirsizlik ortamında, çalışanlar, belirli derecelerde riske girmek durumundadır. Belirsizliğin oluşturduğu bilgisizlik ortamı sebebiyle zamanında verilemeyen kararlar, işletmelerin karşılaştıkları fırsatları yakalayamamalarına ve rekabet avantajı firsatını değerlendirememelerine neden olabilmektedir. Bu yüzden belirsizlik ortamında çalışanların, uygun oranda risk altına girmeleri gerekir. Özellikle işletme yöneticileri, karşılaştıkları fırsatları anında değerlendirebilmek için, ihtiyaç olduğunda planlarını hızla değiştirerek, hatta bulundukları mali sınırları dahi aşarak 
karar vermek durumunda kalabilirler. Araştırmacıların çoğu risk almanın, yöneticilerin öncelikli özelliklerinden birisi olduğunu kabul etmektedir. Çalışanları risk almaya iten güdülerin ise temelde, yenilikçilikle benzer olduğu değerlendirilmekte ve çalışanların yenilikçilik ve risk alma eğilimlerini geliştirmek için ödül sistemleriyle desteklemeleri önerilmektedir (Basım vd., 2008: 125).

Riske girme eğilimini, bireyin kaotik ortamlarda bile çekinmeden teşebbüste bulunmasına yönelik bir davranış olarak tanımlanabilir. Kontrol edilemeyen riskli faktörlerin başarısız sonuçlar üretmesi ihtimali (Türkoğlu vd., 2017: 12), arzu edilmeyen sonuçların ortaya çıkması ihtimaliyle ilişkili tutumların sorumluluğu şeklinde de tanımlanabilmektedir. Diğer ifadeyle riske girmek yenilikçiliğin ön koşuludur (Karahan, 2019) ve içsel motivasyon faktörleri arasında yer almaktadir (Y1lmaz vd., 2014).

Risk kavramını; bir olay, olgu ya da fenomenin gerçekleşmesi, istenmeyen sonuçlarla karşılaşma ihtimali ve bu ihtimalleri değerlendiren sayısal bir olgu olarak ta tanımlanması mümkündür (Davidsson, 2010). Başka bir tanımlamaya göre risk, arzu edilmeyen bir olay veya etkinin ortaya çıkma ihtimali olarak ifade edilmiştir. Risk alma kavramıysa; sonucunun ne olacağını bilmeden, meçhul bir bölgede ya da belirsiz durumlarda karar vermektir (Wakkee vd., 2010:15). Ekonomik hayatta ise risk kavramı; bulanık ortamlardaki yüksek dereceden belirsizlikler sebebiyle, kazanç elde etme esasına göre kar veya zararla karşılaşma olasılığıdır (Brindley, 2005: 155).

Yapılan bazı araştırmalara göre, riske girme becerisi işletme yöneticilerinin önemli bir özelliği olup, girişimci olanların, olmayanlara göre daha fazla risk aldıkları (Norton vd., 2006) ve hatta girişimcilerin riski yönettiği ileri sürülmektedir (Özdemir vd., 2016).

Yenilikçilik, sadece girişimciliğin değil, tüm işletme risklerinin başarı ile sonuçlandırılmasında önemli bir unsurdur. Bunun ana sebebi günümüzde "pazarın artık bütün bir dünya" olarak kabul edilmesiyle rekabet şartlarının kapalı ekonomik sistemlere göre çok daha fazla ağırlaşmasıdır. Değişim o kadar hızlı yaşanmaktadır ki, işletmeler ve onların girişimcileri için rekabet gücünü ellerinde tutmak artık yeterli görülmemektedir. Çünkü rekabet gücünü elde tutmak sadece, işletmenin bir müddet daha ayakta kalmasını sağlamaktadır (İrmiş ve Özdemir, 2011). Bu yüzden günümüzde işletmeler rekabet avantajlarını sürdürülebilir k1lmak zorundadir.

\section{3. İlgili Literatür}

Karahan ve Patır (2019) yaptıkları çalışmada, üniversite öğrencilerinin yenilikçilik seviyelerinin belirlenmesi sayesinde ortaya çıkarılacak eksikler ve sorunların çözümlenmesi, 
günümüzde ekonomik gelişimi temin edecek yenilikçilik yeteneğinin artırılmasına destek sağlamayı amaçlamışlardır. Bu amaçla 312 üniversite öğrencisine anket uygulaması yapılarak araştırmaya katılanların yenilikçiliğin nelerden oluşması gerektiği, konumlandırılması, dağıtımı ve fiyatlandırılmasının nasıl yapılacağı gibi birçok sorun çözümlenmeye çalışılmıştır.

Kasapoğlu (2018) bu araştırmada üniversite yöneticilerinin yenilik ve risk alma davranışlarına ilişkin yönetici ve öğretim elemanlarının görüşlerinin belirlenmesini amaçlamaktadır. Bu amaçla 92 üniversite yöneticisi ile 211 öğretim elemanına anket tekniği uygulanarak yöneticilerden kendilerini değerlendirmeleri istenmiştir. Araştırma sonucunda öncelikle üniversite yöneticileri olmak üzere tüm akademik iş görenlerin yenilikçilik ve risk alma davranışlarını geliştirerek bu alanda liderlik yeteneklerini geliştirmeye katkı sağlayacak etkinlikler düzenlenmesi, ayrıca üniversite öğrencilerinin de yöneticilerin niteliklerini değerlendirmesine yönelik daha fazla akademik çalışmanın yapılması önerilmiştir.

Üstün ve Kılıç (2017) yaptıkları çalışmada, güvenin örgüt içindeki yenilik ve risk alma eğilimine etkisini belirlemeyi amaçlamıştır. Çalışma Eskişehir'de faaliyet gösteren büyük bir sanayi firmasının 227 beyaz yakalı personeline anket uygulaması yapılarak gerçekleştirilmiştir. Çalışmadan elde edilen sonuçlara göre, sanayi firmalarının değişen çevre koşullarına uyum sağlayabilmek, örgütsel performanslarını sürdürebilmek ve arttırabilmek için yenilik yapmak ve risk almaları gerektiği ileri sürülmüştür.

Korucu ve Olpak (2015) yaptıkları araştırmalarında, üniversite öğrencilerinin bireysel yenilikçilik kategorilerine göre dağılımlarını ve bireysel yenilikçilik özelliklerinin farklı değişkenlerle ilişkilerini incelemeyi amaçlamışlardır. Araştırma tarama modeliyle yürütülmüş, 292 üniversite öğrencisinden bilgiler toplanmıştır. Araştırmadan elde edilen sonuçlara göre, öğrencilerin bireysel yenilikçilik düzeylerinin, sınıflarına göre "sorgulayıcı" olduğu ve bireysel yenilikçilik düzeylerinin sınıf düzeylerine göre anlamlı şekilde farklılaştığı ileri sürülmüştür. Bununla birlikte, öğrencilerin bireysel yenilikçilik düzeylerinin cinsiyet ve haftalık internet kullanma sürelerine göre anlamlı derecede farklılaşmadığı tespit edilmiştir.

Işık ve Türkmendağ (2016) yaptıkları çalışmada, üniversite öğrenim görmekte olan öğrencilerin bireysel yenilikçilik seviyelerini belirleyerek, öğrencilerin yenilikçilik yeteneklerini geliştirmeyi amaçlamışlardır. Bu kapsamda 500 öğrencinin bireysel yenilikçilik yetenekleri ile demografik özellikleri arasındaki ilişkiler analiz edilmiştir. Analizlerden elde edilen sonuçlara göre; üniversite öğrenimi gören öğrencilerin cinsiyetleriyle bireysel yenilik yapma yetenekleri arasında değişime direnç boyutunda ve öğrenim görülen bölümle değişime direnç ve fikir önderliği boyutlarında anlamlı farklılıklar bulunmuştur. 
Bülbül (2012) yaptığı araştırmada, okul yöneticilerinin yenilikçilik düzeylerini ölçecek, geçerliliği ve güvenilirliği olan bir ölçme aracı geliştirmeyi amaçlamıştır. Çalışmanın örneklemi, 2010-2011 öğretim yılında Edirne il merkez ilçelerinde ve köylerinde görev yapan 216 okul yöneticisidir. Çalışma sonucunda elde edilen bulgulara göre, geliştirilen ölçeğin okul yöneticilerinin yenilikçilik düzeylerinin ölçülmesinde kullanılabilecek bir araç olduğu ileri sürülmüştür.

Basım, Korkmazyürek ve Tokat (2008) yaptıkları çalışmada, bazı kamu kurumlarında görevli 230 kişiye anket uygulayarak çalışanların yenilikçi davranma ve risk alma eğilimlerinin ölçülmesi amaçlanmıştır. Anket sonuçlarına göre, çalışanların risk alma eğilimleri ortalamanın üzerindedir ve yenilikçi davranışları yüksek seviyelerdedir.

Yılmaz, Şen ve Demirkaya (2014) tarafından yapılan araştırmada, başhemşirelerin yenilikçi ve risk alma davranışları ile bunlarla ilişkili kişisel ve mesleki niteliklerine ilişkin faktörler belirlenmeye çalışılmıştır. Araştırmanın evrenini, 2011 yılı, İstanbul ilinde bulunan Sağlık Bakanlığı'na ait 55 hastanede görevli olan başhemşirelerdir. Çalışmadan elde edilen sonuçlara göre başhemşirelerin yenilikçi ve riskli davranışlarının yüksek seviyede olduğu, 46 yaş ve üstünde olanların diğerlerine göre daha yüksek risk alma davranışına sahip olduğu tespit edilmiştir.

Örün vd., (2015) tarafından yapılan bu çalışmada, öğretmen adaylarının bireysel yenilikçilik profilleri ile teknoloji tutum düzeyleri arasındaki ilişkileri incelemişlerdir. Çalışmanın örneklemi, Anadolu Üniversitesi Eğitim Fakültesi'nde 12 farklı bölümde ve dört farklı sınıf düzeyinde eğitim almakta olan 422 öğretmen adayıdır. Çalışmadan elde edilen sonuçlara göre; yenilikçilik puanlarıyla teknolojiye karşı tutumları arasında pozitif yönlü, anlamlı düzeyde ve orta dereceli ilişkiler vardır.

Tajjedini (2008) yaptığı çalışmada, yenilikçiliğin KOBİ işletmelerinin iş performansına etkilerini araştırmıştır. Çalışmada, yenilikçilik ile işi performansı (yani, kar hedefine ulaşma, satış hedefine ulaşma ve yatırım getirisi başarısı) değişkenlerine ait veriler, 174 İsviçreli KOBİ perakendecisinden yüz yüze görüşme yoluyla toplanmıştır. Elde edilen bulgular daha önce yapılan araştırmalarla karıştırılmış, yenilikçilik faktörlerinin KOBİ perakendecilerinin performansını nasıl etkilediği keşfedilmiş ve konuya yeni bir bakış açısı kazandırılmıştır. Çalışma sonucunda, yenilikçiliği kuramsal stratejinin ayrılmaz bir parçası olarak gören ve müşteri ihtiyaçlarına odaklanan bir iş ortamının oluşturulmasının önemine vurgu yapılmış ve özel olarak, yenilikçilikle birlikte müşteri odaklılığın uzun vadede işletme performansı üzerinde önemli ve olumlu bir etki oluşturacağı ileri sürülmüştür. 


\section{Araştırmanın Amacı ve Metodoloji}

\subsection{Araştırmanın Amacı}

Yapılan bu uygulamalı çalışma, üniversite öğrencilerinin kendine güven, risk alma ve yenilikçilik düzeylerinin belirlenmesi ve karşılaştırma amacıyla yapılmıştır. Böylelikle üniversite öğrencilerinin kendine güven ve risk alma davranışlarının, yenilikçilik kapasitelerini artırması için neler yapılabileceği konusunda öneriler geliştirilebilecek, dolayısıyla günümüzde en önemli rekabet araçlarından sayılan yenilikçilik kapasitesinin artırılmasına katkı sağlanabilecektir. Çalışmaya bilgi sağlamak amacıyla kendine güven, risk alma ve yenilikçilik düzeyini ölçen bir anketle hazırlanmış ve bu anket üniversite öğrenimi görmekte olan öğrencilere uygulanmıştır. Çalışma sonucunda, konu ile ilgili belirlenen sorun ve eksiklikler ve bunlara ait çözüm önerileri geliştirilmeye çalışılacaktır.

\subsection{Araştırmanın Evreni ve Örneklemi}

Araştırmanın evreni Kasım 2019 tarihinde Fırat Üniversitesinin değişik fakültelerinde öğrenim gören öğrenciler oluşturmaktadır. Bu evrenden 504 öğrenci örneklem olarak rastgele yöntemle belirlenmiş ve bu öğrencilerin tüm üniversitelerdeki öğrencileri temsil ettiği kabul edilmiştir.

\subsection{Veri Toplama Aracı}

Araştırmaya veri sağlamak amacıyla yüz yüze anket yöntemi seçilmiştir. Uygulamada kullanılan anket formunun hazırlanması için ilkönce ilgili literatür taraması yapılmış, elde edilen önceki araştırmalarda kullanılan anketler incelenmiş (Karahan ve Patır, 2019; Kasapoğlu, 2018, Üstün, ve Kılıç, 2017; Korucu ve Olpak, 2015; Işık ve Türkmendağ, 2016; Bülbül, 2012; Basım, ve Korkmazyürek, 2008; Yılmaz, ve Şen, 2014; Demirel ve Seçkin, 2008; Örün vd., 2015) ve bu çalışmalardan elde edilen bilgilerden yararlanılarak uygulamada kullanılan yeni bir anket formu hazırlanmıştır.

Geliştirilen bu anket formunda dört bölüm olup bu bölümler; demografik özellikler, öğrencilerin kendine güven, risk alma ve yenilikçilik düzeyini ölçme bölümleridir. Soruları değerlendirilmesi için katılımcılara beşli likert tipi cevap seçenekleri sunulmuş ve öğrencilerin sorulara verdikleri cevaplar, gerekli hesaplamalar yapılarak puana dönüştürülmüştür.

Uygulaması yapılan anket toplam 38 sorudan oluşmakta, bu soruların 8 adedi demografik bilgileri, 5 adedi öğrencilerin kendine güvenini, 5 adedi risk alma ve 20 adedi de yenilikçilik ölçeğine aittir. Ankette bulunan 30 maddelik ölçek için Alfa güvenirlik katsayı hesabı 0.89 olarak bulunmuştur. Elde edilen bu sonuca göre testi yapılan ölçeğin yüksek derecede güvenilir (Yıldız ve Uzunsakal, 2018:19) olduğuna karar verilmiştir. Uygulaması yapılan anketlerden 
elde edilen veriler, bilgisayar ortamına geçirilerek SPSS 22 paket programında gerekli istatistiksel değerlendirmeler yapılmıştır.

\subsection{Araştırmadan Elde Edilen Bulgular ve Yorumlar}

Anketler aracılığıyla elde edilen verilerin SPSS 22 paket programında analizleri yapılarak sonuçlar, dört başlık halinde yorumlanmış ve aşağıya; öğrencilerin demografik özellikleri, kendine güven, risk alma ve yenilikçilik seviyeleri başlıklarıyla ayrıntılı olarak aşağıda yorumlanmıştır.

\subsubsection{Araştırmaya Katılanların Demografik Özellikleri}

Üniversite öğrencilerinin verdikleri bilgilere göre araştırmaya katılan öğrencilerin cinsiyete göre dağılımları; \%58(291) kadın, \%42(213) erkektir. Öğrencilerin yaş durumlarına göre dağılımı; \%87(438) 19-25 yaş aralığında, \%10(50) 18 ve daha düşük yaşlarda, \%3(13) 26-35 yaş aralığındadır. Öğrencilerin fakültelere göre dağılımı ise \%36(180) Fen Edebiyat Fakültesi öğrencisi, \%28(140) İ̈BF öğrencisi, \%16(83) Sağlık Bilimleri fakültesi öğrencisi, \%13(68) diğerleri ve \%7(33) Mühendislik fakültesi öğrencilerdir (Tablo 1).

Tablo 1. Öğrencilerin Demografik Bilgileri

\begin{tabular}{|c|c|c|c|}
\hline & & $\mathrm{F}$ & $\%$ \\
\hline \multirow[t]{3}{*}{ Cinsiyet } & Kadın & 291 & 58 \\
\hline & Erkek & 213 & 42 \\
\hline & 18 ve Alt1 & 50 & 10 \\
\hline \multirow[t]{3}{*}{ Yaş } & $19-25$ & 438 & 87 \\
\hline & $26-35$ & 16 & 03 \\
\hline & İİBF & 140 & 28 \\
\hline \multirow[t]{6}{*}{ Fakülte } & Müh. & 033 & 07 \\
\hline & Fen Edeb. & 180 & 36 \\
\hline & Sağlık Bilim. & 083 & 16 \\
\hline & Diğer & 068 & 13 \\
\hline & 1.sinif & 123 & 24 \\
\hline & 2.sinif & 116 & 23 \\
\hline \multirow[t]{4}{*}{ Sinif } & 3.sinif & 054 & 11 \\
\hline & 4.sinif & 197 & 39 \\
\hline & Uzatmalı & 014 & 03 \\
\hline & Toplam & 504 & 100 \\
\hline
\end{tabular}

Tablo 1'de görüldüğü gibi, öğrencilerin sınıflara göre dağılımı ise \%39(197) dördüncü sınıf, \%24(123) birinci sınıf, \%23(116) ikinci sınıf, \%11(54) üçüncü sınıf öğrencisi, \%3(14) uzatmalı öğrencidir. Konuyla ilgili araştırma yapan Korucu ve Olpak (2015)'da yenilkçilik düzeyinin sınıf seviyesine göre farklılaştığını, üst sınıflara doğru seviyenin arttığını, yani alınan eğitimle yenilikçilik düzeyinin nispeten de olsa yükseliş gösterdiğini belirtmişlerdir. 


\subsection{2. Öğrencilerin Kendine Güven Düzeyleri}

Araştırmaya katılan Fırat Üniversitesinde öğrenim görmekte olan 504 öğrencinin kendine güven seviyesi beş üzerinden, ortalama 4,22 puan olarak hesaplanmıştır. Bu sonuca göre öğrencilerin risk alma düzeyinin yüksek olduğu yorumu yapılmıştır. Aşağıda Tablo 2'de araştırmaya katılan öğrencilerin kendine güven düzeyi puanları ve standart sapmaları gösterilmiştir.

Tablo 2. Öğrencilerin Kendine Güven Düzeyi Ölçeği Ortalama Puanları

\begin{tabular}{|l|c|c|}
\hline \multicolumn{1}{|c|}{ Öğrencilerin kendine güven düzeyleri ortalaması $\mathrm{x}=4,22$} & $\overline{\mathrm{X}}$ & $\S$ \\
\hline 1 Yapacağın bir işi başarmada yeteneklerime güvenirim & 4,37 & 0,918 \\
\hline 2 Denenmemiş yeni işlerin üstesinden gelmede yeteneklerime güven duyarım. & 4,18 & 0,901 \\
\hline 3 Yaptığım işleri en az herkes kadar iyi yaparım. & 4,33 & 0,887 \\
\hline 4 Eleştiriler davranışlarımı olumlu etkiler. & 4,00 & 1,066 \\
\hline 5 İşimle ilgili karşılaşacağım kriz, tehdit ve tehlikelerin üstesinden gelebilirim. & 4,20 & 0,920 \\
\hline
\end{tabular}

Tablo 2'de, kendine güven ölçeğindeki her bir maddenin puan ortalamaları ve standart sapmaları ölçeğin tümünün ortalaması gösterilmiştir.

Araştırmaya katılan öğrencilerin bir işte başarılı olmak için yeteneklerime güvendikleri düşüncesine katılım durumundan aldıkları puana $(\overline{\mathrm{X}}=4,37 ; \mathrm{s}=0,92)$ göre, öğrencilerin çoğunluğu kendine güvenmektedir. Öğrencilerin yeni ve denenmemiş durumlarla baş etmede yeteneklerime güven duydukları düşüncesine katılım durumundan aldıkları puana $(\overline{\mathrm{X}}=4,18$; $\mathrm{s}=0,90)$ göre, öğrencilerin çoğunluğu kendi yeteneklerine güvenmektedirler.

Araştırmaya katılan öğrencilerin işleri en az herkes kadar iyi yapabilecekleri düşüncesine katılım durumundan aldıkları puana göre $(\bar{X}=4,33 ; s=0,89)$, öğrencilerin çoğunluğu işleri başarıyla yapabilecekleri düşüncesindedir. Öğrencilerin eleştiriler davranışlarını olumlu etkilediği düşüncesine katılım durumundan aldıkları puana $(\bar{X}=4,00 ; s=1,06)$ göre, öğrencilerin çoğu eleştirilerin kendilerini olumlu etkilediğine inanmaktadır. Öğrenciler yaptıkları işle ilgili karşılarına çıkan kriz, tehdit ve tehlikelerin üstünden gelebileceklerine inanmaktadırlar $(\overline{\mathrm{X}}=4,20 ; \mathrm{s}=0,92)$.

\subsection{3. Öğrencilerin Risk Alma Düzeyleri}

Araştırmaya katılan 504 öğrencinin risk alma seviyeleri ortalama beş üzerinden, 3,78 puandır. $\mathrm{Bu}$ ortalama puan öğrencilerin risk alma seviyelerinin yüksek olduğu şeklinde yorumlanmıştır. 
Aşağıda Tablo 3'de araştırmaya katılan öğrencilerin risk alma düzeyi puanları ve standart sapmaları gösterilmiştir.

Tablo 3. Öğrencilerin Risk Alma Düzeyi Ölçeği Ortalama Puanları

\begin{tabular}{|l|c|c|}
\hline \multicolumn{1}{|c|}{ Öğrencilerin risk alma düzeyleri ortalaması $\overline{\mathrm{X}}=3,78$} & $\overline{\mathrm{X}}$ & § \\
\hline Görevin başarısına inanırsam her türlü riski üstlenebilirim & 3,81 & 1,191 \\
\hline Başarı olasılığ1 \%40 ve daha düşük olan durumlarda risk alırım. & 3,33 & 1,209 \\
\hline Başka biri ççin çalışacağıma, kendi işimi kurmayı yeğlerim. & 3,98 & 0,992 \\
\hline $\begin{array}{l}\text { Ne gibi bir tepki ortaya çıkacağından emin olmasam da yeni fikirler teklif etmeyi } \\
\text { severim. }\end{array}$ & 3,93 & 0,965 \\
\hline \begin{tabular}{l} 
Riskler tekrar almaya eğilimliyimdir çünkü firsatlarımı artırmak isterim. \\
\hline
\end{tabular} & 3,85 & 1,065 \\
\hline
\end{tabular}

Tablo 3'de, risk alma ölçeğindeki her bir maddenin puan ortalamaları ve standart sapmaları ölçeğin tümünün ortalaması gösterilmiştir.

Anket uygulamasına katılanların, görevin başarısına inandıklarında her türlü riski göze alabileceği düşüncesine katılım durumundan aldıkları puana ( $\bar{X}=3,81 ; s=1,19)$ göre, öğrencilerin çoğunluğu risk alabileceklerini göstermektedir.

Araştırmaya katılan öğrencilerin başarı olasılığı \% 40 ve daha az olması durumu risk alacakları düşüncesine katılım durumundan aldıkları puana $(\bar{X}=3,33 ; \mathrm{s}=1,21)$ göre, öğrencilerin çoğunluğunun risk alabilecekleri söylenebilir. Öğrencilerin başka biri için çalışabileceklerine, kendiişlerini kurmayı tercih edecekleri düşüncesine katılım durumundan aldıkları puana göre $(\bar{X}=3,98 ; s=0,99)$, öğrencilerin çoğunluğu kendi işini kurmayı tercih etmektedir. Öğrencilerin nasıl bir tepki göstereceğinden emin olmadıkları durumlarda bile yeni fikirler ileri sürmek istedikleri düşüncesine katılım durumundan aldıkları puana $(\bar{X}=3,93 ; s=0,96)$ göre, öğrencilerin çoğu yeni fikirler ortaya atmaktan hoşlanmaktadır. Öğrencilerin riskleri tekrar göze almaya eğilimli oldukları, karşılaştıkları fırsatları değerlendirmek istedikleri düşüncesine katılım durumuna $(\bar{X}=3,85 ; s=1,06)$, bakarak çoğunluğun risk almaya eğilimli olduğu yorumu yapılabilir.

\subsection{4. Öğrencilerin Yenilikçilik Düzeyleri}

Araştırmaya katılan Fırat Üniversitesinde öğrenim görmekte olan 504 öğrencinin yenilikçilik seviyesi ortalama, 3,73 puan olarak hesaplanmıştır. Bu sonuç öğrencilerin yenilikçilik farkındalık seviyelerinin yüksek olduğu $(3,73>2,5)$ şeklinde yorumlanabilir. Aşağıda Tablo 4 'te 
araştırmaya katılan öğrencilerin yenilikçilik düzeyi puanları ve standart sapmaları gösterilmiştir.

Tablo 4. Öğrencilerin Yenilikçilik Düzeyi Ölçeği Ortalama Puanları

\begin{tabular}{|c|c|c|}
\hline Öğrencilerin yenilikçilik düzeyleri ortalaması $\overline{\mathrm{X}}=3,73$ & $\overline{\mathrm{X}}$ & s \\
\hline Yenilikleri takip ettiğim için arkadaşlarım sık sık benden bilgi ve öneri alırlar. & 3,84 & 1,071 \\
\hline Yeni şeyleri denemekten hoşlanırım. & 4,37 & 0,917 \\
\hline Bir şey yaparken, yeni yollar olup olmadığını araştırırım. & 4,30 & 0,839 \\
\hline Yeni fikirleri kabul etme konusunda genellikle dikkatli davranırım. & 4,26 & 0,793 \\
\hline Problemleri çözmek için genellikle yeni yöntemler bulurum. & 3,96 & 1,005 \\
\hline Yeni bakış açılan ve yeni buluşlara şüphe ile bakarım. & 3,05 & 1,365 \\
\hline Çevremdeki insanların kabul ettiğini görene kadar yeni fikirleri benimsemem. & 2,92 & 1,386 \\
\hline Yenilikçilik konusunda insanlan kolay etkileyen bir kişi olduğumu düşünürüm. & 3,79 & 1,011 \\
\hline Düşünce ve davranışlarımın yaratıcı ve özgün olduğunu düşünürüm. & 4,05 & 0,967 \\
\hline Çevremdeki insanların arasında yeniliği kabul eden en son kişi olduğumu düşünürüm. & 2,73 & 1,520 \\
\hline Yaratıcı bir kişi olduğumu düşünüyorum. & 4,04 & 0,921 \\
\hline Yenilikler konusunda gruba liderlik etmekten hoşlanurım. & 3,94 & 1,074 \\
\hline $\begin{array}{l}\text { Çevremdeki insanların işine yaradığını görünceye kadar yenilikleri kabul etmede } \\
\text { isteksiz davranırım. }\end{array}$ & 3,05 & 1,357 \\
\hline Düşünce ve davranışlarımla çevremdekileri özgün olmaya teşvik ettiğimi düşünürüm. & 3,84 & 1,030 \\
\hline $\begin{array}{l}\text { Eski yaşam tarzının ve işleri eski yöntemlerle yapmanın en iyi yol olduğunu } \\
\text { düşünürüm. }\end{array}$ & 3,18 & 1,298 \\
\hline Problemlere ve belirsizliklere karși mücadele ederim. & 4,15 & 0,941 \\
\hline $\begin{array}{l}\text { Yenilikleri dikkate almadan önce diğer insanların o yeniliği kullandığını görmek } \\
\text { isterim. }\end{array}$ & 3,81 & 1,113 \\
\hline Yeni fikirlere açık birivim. & 4,30 & 0,902 \\
\hline Cevaplanmamış sorular beni çōzüm bulmaya yöneltir. & 4,01 & 0,939 \\
\hline Yeni fikirlere karşı şüpheci davranırım. & 3,07 & 1,331 \\
\hline
\end{tabular}

Tablo 4'de, ölçekteki her bir maddenin puan ortalamaları ve standart sapmaları ölçeğin tümünün ortalaması gösterilmiştir.

Araştırmaya katılan öğrencilerin yenilikleri takip ettiğim için arkadaşlarının sıkça kendisinden bilgi ve önerilerini aldıkları fikrine katılım durumundan aldıkları puana $(\overline{\mathrm{X}}=3,84$;

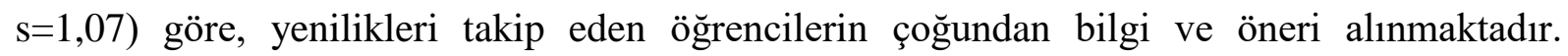
Öğrencilerin, yeni şeyleri denemekten hoşlandıkları düşüncesine katılım puanına $(\bar{X}=4,37$; $\mathrm{s}=0$,92) bakarak, öğrencilerin çoğunun yeni şeyleri denemekten çok zevk aldıkları yorumu yapılabilir. Öğrencilerin "bir iş yaparken, işin yeni yollarının olup olmadığını araştırdıkları" ifadesine katılım puanına ( $\overline{\mathrm{X}}=4,30 ; \mathrm{s}=0,84)$ göre, öğrencilerin çoğunun bir işin yeni yapılış yolların olup olmadığını araştırmaktadır. Öğrencilerin yeni düşünceleri kabullenmek hususunda genellikle dikkatli davranmak gerektiği düşüncesi katılım puanına göre $(\overline{\mathrm{X}}=4,26$; $s=0,79)$, öğrencilerin büyük çoğunluğunun yeni fikirleri kabul etmede temkinli davrandıkları yorumu yapılabilir. 
Öğrencilerin problemleri çözmek için genellikle yeni yöntemler bulma düşüncesi katılım puanına göre $(\bar{X}=3,96 ; s=1,00)$, çoğu öğrenci problemleri çözmek için yeni yöntemler bulmayı benimsemektedir.

Anket sonuçlarına göre, öğrenciler davranış ve düşüncelerinin kendilerine özgün olduğu düşüncesine katılım puanına göre $(\bar{X}=4,05 ; \mathrm{s}=0,97)$, öğrencilerin büyük bir kısmının kendilerini yaratıcı ve özgün gördüğü yorumu yapılabilir. Öğrencilerin yeniliklerle ilgili insanları kolayca etkileyebilen bir kişilik olduğu düşünmesi katılım puanına göre $(\bar{X}=3,79 ; s=1,01)$, çoğunluk kendisini yenilikçilik konusunda etkileyici olarak nitelendirmektedir. Öğrencilerin kendini yaratıcı bir kişi olduğunu düşünmesi katılım puanına göre $(\bar{X}=4,04 ; s=0,92)$, öğrencilerin büyük bir çoğunluğu tarafindan kabul görmektedir. Öğrencilerin yenilikler konusunda gruba liderlik etmekten hoşlandıkları düşüncesi katılım puanına göre $(\bar{X}=3,94 ; s=1,07)$, öğrencilerin çoğunun yenilik konusunda gruba liderlik arzusu içinde oldukları ifade edilebilir. Öğrencilerin fikirleri ve davranışları ile çevresindekileri özgünlüğe teşvik ettiği düşüncesi katılım puanına göre $(\bar{X}=3,84 ; s=1,03)$, öğrencilerin büyük bir çoğunluğu kendi düşüncelerinin çevresindekiler üzerinde özgün olmaya teşvik ettiği kanısına ulaşılabilir.

Araştırmaya katılan öğrencilerin problemlere ve belirsizliklere karşı mücadele etmesi düşüncesi katılım puanına göre $(\bar{X}=4.15 ; s=0,94)$, öğrencilerin büyük bir çoğunluğunun problemlere ve belirsizliklere karşı mücadele ettiği yorumu yapılabilir. Öğrencilerin yenilikleri benimsemeden önce başkalarının onu kullandıklarını görmek istedikleri düşüncesi katılım puanına göre $(\overline{\mathrm{X}}=3,81 ; \mathrm{s}=1,11)$, öğrencilerin çoğunun bahsi geçen yenilik konusunda ilk tecrübeyi kendisinin yaşamak istemediği yorumu yapılabilir. Öğrencilerin "yeni fikirlere açık biriyim" ifadesi katılım puanına göre $(\bar{X}=4,30 ; s=0,90)$, öğrencilerin çoğunun yeni fikirlere açık oldukları yorumu yapılabilir. Araştırmaya katılan öğrencilerin cevaplanmamış soruların kendisini çözüm bulmaya yönelmesi düşüncesi katılım puanına göre ( $\bar{X}=4,01 ; s=0,94)$, öğrencilerin çoğunun cevaplanmamış soruların çözümünü bulması konusunda hevesli olduğu kanısına varılabilir.

Araştırmaya katılanların yeniliklere bakışları ve yeni yapılan buluşlara şüpheyle baktıkları düşüncesine katılım puanlarına bakarak ( $\bar{X}=3,05 ; s=1,36)$, öğrencilerin çoğunun bu düşünceyi benimsemedikleri (ortalama 3,73>3,05 olduğundan) ifade edilebilir. Öğrencilerin çevrelerindekilerin kabul ettiğini görene kadar yeni fikirleri benimsememesi düşüncesi katılım puanına göre ( $\overline{\mathrm{X}}=2,92 ; \mathrm{s}=1,38)$, öğrencilerin çoğu yeni fikirleri benimsemesinde çevresindeki insanların rolünün düşük olduğu söylenebilir. 
Anket uygulamasına katılan öğrencilerin çevrelerindekiler tarafından en son yeniliği kabul eden kişi olarak nitelendirildiği düşüncesine katılım puanına $(\bar{X}=2,73 ; s=1,52)$ göre, bu fikir öğrencilerin çoğu tarafindan benimsenmemektedir. Öğrencilerin yeniliği çevremdekilerin işine yaradığını görünceye kadar kabulde çekingen davrandığı düşüncesi katılım puanına göre $(\bar{X}=3,05 ; s=1,36)$, bu fikir çoğunluk tarafından kabul görmemektedir. Öğrencilerin eski yaşam tarzlarının ve yöntemlerinin en iyi yol olduğu düşüncesine katılım puanlarına göre $(\bar{X}=3,18$; $s=1,30$ ), çoğunluk bu fikri pek kabul etmemektedir. Öğrencilerin yeni fikirlere karşı şüpheci davrandığı düşüncesi katılım puanlarına göre $(\bar{X}=3,07 ; s=1,33)$, çoğunluk yeni fikirlere şüpheci davranmaktadır yorumu yapılabilir.

\subsubsection{Yenilikçilik ile Kendine Güven ve Risk Alma Seviyeleri Arası İlişkiler}

Araştırmaya katılan öğrencilerin yenilikçilik düzeyi ile kendine güven ve risk alma davranışları arasındaki ilişkileri belirlemek üzere yapılan korelasyon analizi sonucu aşağıda Tablo 5'de gösterilmiştir.

Tablo 5. Yenilikçilik ve Risk Alma Arasındaki Korelasyon

\begin{tabular}{|l|l|r|r|r|}
\hline \multicolumn{2}{|c|}{} & \multicolumn{1}{c|}{ Güven } & Yenilikçilik & \multicolumn{1}{c|}{ Risk } \\
\hline \multirow{2}{*}{$\begin{array}{l}\text { Güven Duyma } \\
\text { Ortalamas1 }\end{array}$} & Pearson Correlation & 1 & $0,600^{* *}$ & $0,372^{* *}$ \\
\cline { 2 - 5 } & Sig. (2-tailed) & & 0,000 & 0,000 \\
\hline \multirow{2}{*}{$\begin{array}{l}\text { Yenilikçilik } \\
\text { Ortalamas1 }\end{array}$} & Pearson Correlation & $0,600^{* *}$ & 1 & $0,475^{* *}$ \\
\cline { 2 - 5 } & Sig. (2-tailed) & 0,000 & & 0,000 \\
\hline \multirow{2}{*}{$\begin{array}{l}\text { Risk alma } \\
\text { Ortalamas1 }\end{array}$} & Pearson Correlation & $0,372^{* *}$ & $0,475^{* *}$ & 1 \\
\cline { 2 - 5 } & Sig. (2-tailed) & 0,000 & 0,000 & \\
\cline { 2 - 5 } & $\mathrm{N}$ & 504 & 504 & 504 \\
\hline
\end{tabular}

**. Correlation is significant at the 0.01 level (2-tailed).

Tablo 5'de görülmekte olduğu gibi, üniversite öğrencilerinin yenilikçilik düzeyi ile kendine güven düzeyi arasındaki ilişkiyi belirlemek üzere yapılan basit doğrusal korelasyon analizi sonucuna göre; yenilikçilik düzeyi ile kendine güven düzeyi arasında pozitif yönlü ve anlamlı bir ilişki olduğunu belirlenmiştir $(R=0,600, p<0,00)$.

Tablo 5'de görüldüğü gibi, üniversite öğrencilerinin yenilikçilik düzeyi ile risk alma düzeyi arasındaki ilişkiyi belirlemek üzere yapılan basit doğrusal korelasyon analizi sonucuna göre; yenilikçilik düzeyi ile risk alma düzeyi arasında pozitif yönlü ve anlamlı bir ilişki olduğunu tespit edilmiştir $(\mathrm{R}=0,475, \mathrm{p}<0,00)$.

Tablo 5 ve Şekil 1'de görüldüğü gibi, üniversite öğrencilerinin risk alma düzeyi ile kendine güven düzeyi arasındaki ilişkiyi belirlemek üzere yapılan basit doğrusal korelasyon sonucuna 
göre; öğrencilerin risk alma düzeyleriyle, kendilerine güven düzleri arasında pozitif ve anlamlı seviyede bir ilişki bulunduğu görülmektedir $(\mathrm{R}=0,372, \mathrm{p}<0,00)$.

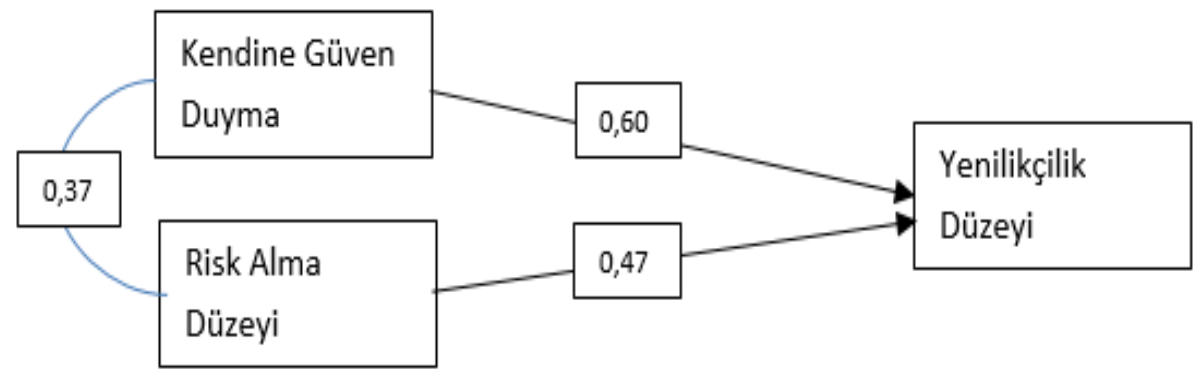

Şekil 1. Değişkenler arası ilgileşim oranları

Ayrıca öğrencilerin kendine güven düzeyindeki değişim, yenilikçilik düzeyindeki değişimin \%36' sını $\left(\mathrm{R}^{2}=0,600^{2}=0,3600\right)$ açıklayabilmektedir. Bu sonuçlara göre; öğrencilerin kendine güven düzeyi arttıkça yenilikçilik düzeyleri de artmaktadır yorumu yapılabilir. Yani kendine güven arttıkça daha fazla yenilik fikirleri ortaya çıkabilmektedir denilebilir. Bununla birlikte, öğrencilerin risk alma düzeyindeki değişim, yenilikçilik düzeyindeki değişimin \%22'sini $\left(\mathrm{R}^{2}=0,475^{2}=0,225\right)$ açıklayabilmektedir. Bu sonuçlara göre; öğrencilerin risk alma düzeyi arttıkça yenilikçilik düzeyleri de artmaktadır yorumu yapılabilir.

Son olarak, öğrencilerin risk alma düzeylerindeki değişim, kendine güven düzeyindeki değişimin \%14'sini $\left(\mathrm{R}^{2}=0,372^{2}=0,138\right)$ açıklayabilmektedir. Bu sonuçlara göre; öğrencilerin risk alma düzeyi arttıkça kendine güven düzeyleri de bir miktar artmaktadır yorumu yapılabilir.

\section{Sonuç}

Risk alma davranışının yeniliğe etkisi, günümüzün en etkili rekabet araçlarından birisi olan yenilikçilik düzeyini artırmak ve yaygınlaştırmak anlamında oldukça önemlidir. Bu yüzden günümüzde yenilikçilik ve risk alma konusunda yapılan oldukça fazla çalışma bulunmakta (Kasapoğlu, 2018; Üstün ve Kılıç, 2017; Yılmaz ve Demirkaya, 2014; Basım ve Tokat, 2008; Tajjedini, 2008) ve bunların hepsi konunun önemine dikkat çekmektedir. Buradan yola çıkarak yapılan bu çalışmada günümüzün en etkili rekabet araçlarından birisi olan yenilikçilik ile risk alma arasındaki ilişkinin araştırılmasına karar verilmiştir.

$\mathrm{Bu}$ kapsamda yapılan çalışmadan elde edilen sonuçlara göre; Frrat Üniversite'sinde öğrenim gören 504 üniversite öğrencisinin yenilikçilik düzeyi 5 puan üzerinden yapılan hesaplamada 3,73 olarak bulunmuştur. Yılmaz ve Şen (2014) tarafından yapılan çalışmada da hemşirelerin yenilikçilik düzeylerinin de, aynı şekilde yüksek yani iyi düzeyde olduğu belirlenmiştir. Karahan ve Patır (2019) ekonomik gelişmenin yenilikçilik yeteneğini 
artıracağını, Kasapoğlu (2018) yenilik yeteneğinin geliştirilerek liderlik yeteneklerinin de geliştirilebileceğini, Üstün ve Kılıç (2017) örgütsel performansı artırmak için yenilik ve risk yeteneklerinin artırılması gerektiğini ileri sürmüşlerdir.

Aynı öğrencilerin kendine güven düzeyi ise 5 puan üzerinden 4,22 ve risk alma düzeyi 3,78 puan hesaplanmıştır. Basım, Korkmazyürek ve Tokat (2008) tarafından yapılan çalışmada risk alma seviyesinin ortalamanın üstünde yani iyi düzeyde olduğu, bu ortalamalara göre öğrencilerin ilgili konulardaki farkındalık seviyelerinin yüksek olduğu yorumu yapılmıştır.

Yenilik düzeyi ortalamas1 3,73'ün üzerinde olan öğrenciler; yenilikleri izlediklerinden arkadaşlarının sıkça kendilerinden bilgiler ve öneriler talep ettiklerini, yenilikleri denemeden çok zevk aldıklarını, bir iş yaparken yeni yolların olup olmadığını araştırdıklarını, yeni fikirleri kabul etme konusunda temkinli davrandıkları, problemleri çözmek için yeni yöntemler bulmayı tercih ettiklerini ifade etmişlerdir. Ayrıca, öğrenciler kendilerini yaratıcı ve özgün gördüklerini ve yeni fikirleri benimsemesinde çevresindeki insanların rolünün düşük olduğunu ifade etmişlerdir.

Yenilikçilik düzeyi ortalaması 3,73'ün altında olan öğrenciler, yeni buluşlara şüphe ile baktıkları, yeni fikirleri kabullenmede çevresindeki insanların rolünün olduğu, yeniliği kabul eden en son kişi oldukları yorumları yapılabilir.

Araştırmadan elde edilen sonuçlara göre üniversite öğrencilerinin yenilikçilik düzeyi ile kendine güven ve risk alma düzeyi arasındaki ilişkiyi belirlemek üzere yapılan ilişki (korelasyon-ilgileşim) analizi sonucuna göre; yenilikçilik düzeyi ile kendine güven ve risk alma düzeyi arasında anlamlı ilişsiler bulunmuştur. Ayrıca, kendine güven ile risk alma durumları arasında da, az da olsa anlamlı ilişki bulunmuştur. Bu göre; öğrencilerin kendine güvenleri ve risk alma düzeyleri arttıkça yenilikçilik düzeylerinin de arttığı (Basım, Korkmazyürek ve Tokat (2008)'da aynı görüşleri savunmuştur), kendine güven düzeyi arttıkça risk alma davranışının az da olsa arttığı yorumları yapılabilir.

\subsection{Araştırmanın kısıtları ve gelecekte yapılacak araştırmalar için öneriler}

Her araştırma projesinde olduğu gibi, bu çalışmada da tartışılması gereken bazı sınırlamalar bulunmaktadır. Bunlardan birincisi, çalışmanın evreninin bölgesel düzeyde ve bir tek üniversitedeki öğrencilerle sınırlı olmasıdır. Bu yüzden elde edilen sonuçları diğer bölgelere ve sektörlere veya ülke çapında genellemek uygun olmayabilir. İkincisi, elde edilen tüm verilerin belirli bir zaman kesitinde toplanmış olmasıdır. Bu nedenle, elde edilen sonuçlar ve değişken değerleri zamanın belirli bir noktasındaki ilişkileri göstermektedir, bu nedenle genellemek doğru olmayabilir. 
Gelecekte yapılacak araştırmalar için üç ana öneri yapılabilir. İlk olarak çalışmadaki test modelinin yeni örnek guruplarda farklı bir zaman diliminde tekrarlanması, ikici olarak da, farklı endüstri sektörleri için özdeş bir model kullanılarak çalışmanın tekrarlanması; ardından tahmin edilen yapısal parametrelerin karşılaştırılması ile daha ilginç sonuçlar elde edilebilir. Son olarak da, modele daha fazla değişken dâhil edilerek farklı karşılaştırmalar yapılabilir ve değişskenler arasındaki nedenselliklerin belirlenmesine yardımcı olunabilir. 


\section{KAYNAKÇA}

Akkaya, D.T., Yıldız, E. ve Akın, Y. (2014). Üniversite Öğrencilerinin Girişimci Kişilik Özelliklerinin Değerlendirilmesi: Yalova Meslek Yüksekokulu Öğrencilerine Yönelik Bir Uygulama, Yalova Sosyal Bilimler Dergisi, Cilt 4, Sayı 8, s.108-122.

Basım, H. Nejat, Korkmazyürek, H. ve Tokat, O. (2008). Çalışanların Öz Yeterlilik Algılamasının Yenilikçilik ve Risk Alma Üzerine Etkisi: Kamu Sektöründe Bir Araştırma. Selçuk Ünv. Sosyal Bilimler Enstitüsü Dergisi, 2008; 19: 121-130.

Bozkurt, Ö. ve Erdurur, K. (2013). Girişimci Kişilik Özelliklerinin Girişimcilik Eğilimindeki Etkisi: Potansiyel Girişimciler Üzerinde Bir Araştırma, Girişimcilik ve Kalkınma Dergisi Cilt 8, Sayı2, s.57-78.

Brindley, C. (2005). Barriers to Women Achieving Their Entrepreneurial Potential: Women and Risk. International Journal of Entrepreneurial Behaviour \& Research, 11(2): 144-161

Bülbül Tuncer (2012) Okullarda yenilik yönetimi ölçeğinin geliştirilmesi: Geçerlilik ve güvenirlik çalışması 12(1) ss: $157-175$.

Davidsson, M. (2010). Risk Management in A Pure Unit Root. The Journal of Risk Finance, 11(2): 224-234.

Demiralay, Remziye; Bayır, Esma Aybike; Gelibolu, Mehmet Fikret (2016). Öğrencilerin Bireysel Yenilikçilik Özellikleri ile Çevrimiçi Öğrenmeye Hazır Bulunuşlukları İlişkisinin İncelenmesi. Eğitim ve Öğretim Araştırmaları Dergisi, Cilt:5, Sayı:1 Makale.18.

Drucker, P. F. (1985). Innovation and Entrepreneurship. Harper ve Row Publishers: New York.

Işık, C. ve Türkmendağ T. (2016). Atatürk Üniversitesi Turizm Fakültesi Öğrencilerinin Bireysel Yenilikçilik Algılarının Belirlenmesi. Turizm Fakültesi Dergisi :70-99.

İrmiş Ayşe ve Özdemir Lütfiye (2011). Girişimcilik ve Yenilik İlişkisi. Yönetim Bilimleri Dergisi, 9(1), s.136161.

Kara, M. U. (2019). Mesleki Ve Teknik Anadolu Lisesinde Çalışan Öğretmenlerin Eğitimde Teknoloji Kullanım Tutumları ve Bireysel Yenilikçilik Düzeylerinin İncelenmesi (Küçükçckmece Örneği), Yüksek Lisans Tezi, Marmara Üniversitesi İstanbul Sabahattin Zaim Üniversitesi Eğitim Yönetimi ve Denetimi Ortak Yüksek Lisans Programı, İstanbul.

Karahan, M. (2019). Teknoloji ve Yenilik Yönetimi, Akademisyen Kitabevi, Ankara.

Karahan, M. ve Patır, S. (2019). Üniversite Öğrencilerinin Bireysel Yenilikçilik Kapasitelerinin Belirlenmesi. Siirt Ünv. Sosyal Bilimler Enstitüsü Dergisi, Cilt 7, Sayı 13, s.42-58.

Kasapoğlu, Hülya (2018). Üniversite Yöneticilerinin Yenilikçilik ve Risk Alma Davranışlarına İlişkin Yönetici ve Öğretim Elemanlarının Görüşleri. Yüksek Öğretim Dergisi. Cilt:8 Sayı:1, s.45-54.

Korucu, A.T. ve Olpak, Y.Z. (2015). Öğretmen Adaylarının Bireysel Yenilikçilik Özelliklerinin Farklı Değişkenler Açısından İncelenmesi, Eğitim Teknolojisi Kuram ve Uygulama, Cilt:5 Sayı:1, s.111.

Norton, J.R., William, I. ve William, M.T. (2006). The Influence of Entrepreneurial Risk Assessment on Venture Launch or Growth Decisions. Small Business Economics, 26: 215-226.

Örün, Özgür, Orhan, Derya, Dönmez, Pelin ve Kurt, Adile Aşkım (2015). Öğretmen Adaylarının Bireysel Yenilikçilik Profilleri ve Teknoloji Tutum Düzeyleri Arasındaki İlişkinin İncelenmesi, Trakya Üniversitesi Eğitim Fakültesi Dergisi, Cilt 5, Sayı 1, s.65-76.

Özdemir Aydın, Saygılı, Metin ve Yıldırım, Kadir (2016). Risk Alma Eğilimi ve Başarma İhtiyacının Girişimcilik Potansiyeline Etkisi: Üniversite Öğrencileri Üzerine Bir Araştırma, İşletme Bilimi Dergisi, 4(2): 121-140.

Özden, K. Temurlenk, M.S. ve Başar, S. (2008). Girişimcilik Eğilimi: Kırgızistan-Türkiye Manas Üniversitesi ve Atatürk Üniversitesi Öğrencileri üzerine bir Araştırma, Review of Social, Economic, 2008kenanozden.com http://kenanozden.com/docs/yazi/yazi_1_0000.pdf, Erişim Tarihi: 27.02.2021.

Kayhan, Tajeddini and Myfanwy, Trueman (2008). Effect of customer orientation and innovativeness on business performance: a study of small-sized service retailers, Int. J. Entrepreneurship and Small Business, Vol. 6, No. 2, pp.280-295.

Türkoğlu, T., Tetik, S., Açıkgöz, A. (2017). Meslek Yüksekokulu Öğrencilerinin Sosyo-Demografik Özellikleri İle Girişimci Kişilik Özellikleri Arasındaki İlişkinin Araştırılması, Journal of Yasar University, 2017, 12/45, 1-13.

Uzkurt, C. (2008). Pazarlamada Değer Yaratma Aracı Olarak Yenilik Yönetimi ve Yenilikçi Örgüt Kültürü, İstanbul: Beta Yayıncilik.

Ünal, H. (2014). Üniversite Öğrencilerinin Bireysel Yenilikçilik Kategorilerinin Belirlenmesi. Uluslararası Hakemli Akademik Spor, Sağlık ve Tıp Bilimleri Dergisi. Sayı:11 Cilt:4, s.68-74.

Üstün, F. ve Kılıç K. (2017). Örgüte duyulan güvenin, örgütsel yenilik yönetimi ve risk alma davranışı üzerine etkisi. İktisadi ve İdari Bilimler Dergisi 10(2) ss:228-238.

Wakkee, I., Elfring, T., ve Monaghan, S. (2010). Creating Entrepreneurial Employees in Traditional Service Sectors The Role of Coaching and Self Efficacy. International Entrepreneurship Management, 6: 1-21.

Yıldız, D. Ve Uzunsakal, E. (2018). Alan Araştırmalarında Güvenilirlik Testlerinin Karşılaştırılması ve Tarımsal Veriler Üzerine Bir Uygulama, Uygulamalı Sosyal Bilimler Dergisi, 2018, Sayı: 1, s.14-28. 
Yılmaz, Ramazan ve Beşkaya, Yaşar Murat (2018). Eğitim Yöneticilerinin Yaşam Boyu Öğrenme Eğilimleri ile Bireysel Yenilikçilik Düzeylerinin İncelenmesi. Ankara Üniversitesi Eğitim Bilimleri Fakültesi Dergisi. Cilt:51, Say1:1, s.159-181.

Yılmaz, Taşkın; Feride, Tiryaki Şen, Hanife (2014). Başhemşirelerin Yenilikçilik ve Risk Alma Davranışının Belirlenmesi. Balıkesir Sağlık Bilimleri Dergisi. Cilt 3, Sayı 3, s.147-154. 